\title{
Lyme Disease Bacterium, Borrelia burgdorferi Sensu Lato, Detected in Multiple Tick Species at Kenora, Ontario, Canada
}

John D Scott ${ }^{1 *}$, Kerry L Clark ${ }^{2}$, John F Anderson ${ }^{3}$, Janet E Foley ${ }^{4}$, Monica R Young ${ }^{5}$ and Lance A Durden $^{6}$

${ }^{1}$ Research Division, Lyme Ontario, 365 St. David Street South, Fergus, Ontario, Canada N1M 2L7

${ }^{2}$ Environmental Epidemiology Research Laboratory, Department of Public Health, University of North Florida, 1 UNF Drive, Jacksonville, Florida 32224

${ }^{3}$ Department of Entomology and Center for Vector Ecology and Zoonotic Diseases. The Connecticut Agricultural Experiment Station, 123 Huntington

St., New Haven, Connecticut 06511

${ }^{4}$ Department of Medicine and Epidemiology, School of Veterinary Medicine, University of California, 1320 Tupper Hall, Davis, California 95616

${ }^{5}$ Centre for Biodiversity Genomics, University of Guelph, Guelph, Ontario, Canada N1G 2W1

${ }^{6}$ Department of Biology, Georgia Southern University, 4324 Old Register Road, Statesboro, Georgia 30458, USA

\begin{abstract}
We detected the Lyme disease bacterium, Borrelia burgdorferi sensu lato (s.l.), in 8 species of ixodid ticks (Acari: Ixodidae) collected from mammalian hosts, including humans, at Kenora, Ontario, Canada. These 8 tick species include Ixodes angustus, Ixodes banksi, Ixodes cookei (groundhog tick), Ixodes gregsoni, Ixodes muris (mouse tick), Ixodes scapularis (blacklegged tick), Haemaphysalis leporispalustris (rabbit tick), and Dermacentor albipictus (winter tick). Based on PCR amplification, 39 (41\%) of 94 ticks tested were positive for $B$. burgdorferi s.I. DNA sequencing of the flagellin B $(f l a B)$ gene of $B$. burgdorferi s.l. complex revealed the presence of $B$. burgdorferi sensu stricto (s.s.), which is pathogenic to humans, and causes diverse neurological manifestations in patients. Notably, we provide the first record of $B$. burgdorferi s.I. in I. gregsoni, and reveal a new distribution record for this tick in eastern and central Canada by extending the known range westward by $200 \mathrm{~km}$. Our findings indicate that there may be a wide-ranging enzootic transmission cycle of $B$. burgdorferi s.I. within the ecosystem throughout the Kenora area. The health-care profession must be fully cognisant that Lyme disease is present in the Kenora area, and is a public health risk.
\end{abstract}

Keywords: Ticks; Mammalian hosts; Lyme disease; Borrelia burgdorferi sensu lato; Kenora; Ontario; Epidemiology; Public health

Abbreviations: PCR: Polymerase Chain Reaction; CNS: Central Nervous System

\section{Introduction}

The Lyme disease bacterium, Borrelia burgdorferi sensu lato (s.l.), is typically transmitted to mammalian hosts, including humans, by ixodid (hard-bodied) ticks (Acari: Ixodidae) [1]. Each tick species has its own set of suitable hosts, and Lyme disease, a zoonosis, is incidental to humans and domestic animals [2,3]. Left untreated or inadequately treated, Lyme disease can inflict a myriad of multisystemic clinical manifestations.

The first isolation of B. burgdorferi s.l. in mainland Ontario [4] was from a blacklegged tick, Ixodes scapularis (northern populations formerly considered as Ixodes dammini), collected from a dog with no history of travel that was living in Kenora, Ontario. A 10-year tick-host study (1993-2002), which was conducted across Ontario, revealed several B. burgdorferi s.l.-infected I. scapularis ticks on domestic animals and humans in the Kenora District [5]. Recently, Scott et al. [6] documented an established population of I. scapularis on Corkscrew Island, which is $20 \mathrm{~km}$ southwest of Kenora. This hyperendemic
Lyme disease area has the highest infection prevalence of B. burgdorferi s.l. ever reported in Canada. It is evident that the climate in the Kenora area provides an environment that is conducive for I. scapularis reproduction.

Across North America, several Ixodes species are vector competent for B. burgdorferi s.l., including I. affinis, I. angustus, I. dentatus, I. jellisoni, I. minor, I. muris, I. scapularis, and I. spinipalpis [7]. Of these ticks, immature stages of I. affinis, I. dentatus, I minor, I. muris, I. scapularis, and I. spinipalpis, and all host-seeking stages of I. muris can parasitize birds, and can be transported long distances into Canada during northward spring migration [8-17]. Each of these ixodid ticks has the ability to acquire spirochetes while feeding on an infected host and, during the moult, pass them transstadially to the next life stage.

*Corresponding author: John D Scott, Research Division, Lyme Ontario, 365 St. David Street South, Fergus, Ontario N1M 2L7, Tel: 519-843-3646; E-mail: jkscott@bserv.com

Received February 20, 2017; Accepted March 13, 2017; Published March 20, 2017

Citation: Scott JD, Clark KL, Anderson JF, Foley JE, Young MR, et al. (2017) Lyme Disease Bacterium, Borrelia burgdorferi Sensu Lato, Detected in Multiple Tick Species at Kenora, Ontario, Canada. J Bacteriol Parasitol 8: 304. doi:10.4172/21559597.1000304

Copyright: ( 2017 Scott JD, et al. This is an open-access article distributed under the terms of the Creative Commons Attribution License, which permits unrestricted use, distribution, and reproduction in any medium, provided the original author and source are credited. 
Subsequently, Lyme disease spirochetes can be transmitted to vertebrate hosts, including humans.

The aim of this study was to identify species of ticks in the Kenora District that may be involved in the enzootic cycle of B. burgdorferi s.l.

\section{Materials and Methods}

\section{Study area}

Ticks were collected from humans, domestic and wildlife animals within $50 \mathrm{~km}$ of Kenora, Ontario, Canada $\left(49^{\circ} 46^{\prime} \mathrm{N}, 94^{\circ} 29^{\prime} \mathrm{W}\right)$ on the northern edge of Lake of the Woods. This geographic area lies within the Canadian shield, which is comprised of Precambian igneous rock. The coniferous-deciduous forest lies within the boreal forest region, and consists primarily of: red pine, Pinus resinosa; eastern white pine, Pinus strobus; black spruce, Picea mariana; white spruce, Picea glauca; white birch, Betula papyrifera; trembling aspen, Populus tremuloides; bur oak, Quercus macrocarpa; and Manitoba maple, Acer negundo.

\section{Tick collection}

Ticks were collected from injured wild mammals, domestic animals, and from local residents, and submitted to local wildlife rehabilitators, wildlife biologists, and veterinarians. These ticks were removed using finepointed, stainless steel tweezers. Live ticks were placed in round-bottom, $8.5 \mathrm{~mL}$ polypropylene tubes $(15.7 \mathrm{~mm} \times$ $75 \mathrm{~mm}$ ) (Sarstedt) with attached labels specifying host, date collected, geographic location, and collector's name. A 7-mm hole in the polyethylene cap $(15.7 \mathrm{~mm})$ provided ventilation for ticks and, to prevent the ticks from escaping, fine tulle netting was stretched over the open end of the tube before the push-cap was inserted. The tube, which contained the ticks from a single host, was placed in a double-zippered plastic bag to maintain high humidity.
Dead and damaged ticks were put in $2 \mathrm{~mL}$ micro tubes containing 94\% ethyl alcohol. Both live and dead ticks were sent to the tick identification lab (JDS).

Fully engorged immature ticks were held to molt to the next developmental life stage. These engorged ticks were placed in $8.5 \mathrm{~mL}$ polypropylene tubes with a slightly moistened piece $(5 \mathrm{~cm} \times 5 \mathrm{~cm})$ of chlorine-free paper towel. The open end of the tube was covered with tulle netting before the open-centered push cap was inserted. The tubes were placed in a double-zipper plastic bag with a slightly moistened paper towel to provide adequate humidity ( 95\%). A full spectrum, 12W LED, LifeLite light bulb (LifeEnergy Systems), on a timer, was set for a summertime photoperiod (16:8/L:D). Each plastic bag, which contained replete ticks, was checked every 3-5 days to assess the progress of the moult and to ensure that sufficient humidity was maintained. A log sheet was kept for each tick to record the dates checked, advancement of the moult, and the number of days to complete the moult.

\section{Spirochete detection}

Field-collected ticks were sent to 3 different laboratories for $B$. burgdorferi s.l. testing because the first two laboratories had policy changes during the study, and stopped testing ticks. The 3 laboratory periods are: May 2013-June 2013 (JFA), July 2014-June 2015 (KLC), and July 2015-November 2016 (JEF). At lab A (JFA), live ticks from mammalian hosts were cultured in BarbourStoenner-Kelly (BSK) medium, and dead ticks were tested directly using DNA extraction and PCR testing. The DNA detection protocols have been described previously [18-20]. Although Persing et al. [18] employed both the flagellin $(f l a)$ gene and the major outer surface protein $(O s p A)$ gene, lab A only used the OspA gene. Appropriate negative and positive controls were used.

In the second part of the study, ticks were placed in $94 \%$

\begin{tabular}{|c|c|c|c|c|c|c|c|c|}
\hline \multirow{2}{*}{ Tick species } & \multirow{2}{*}{ Host species (no.) } & \multirow{2}{*}{$\begin{array}{l}\text { No. of } \\
\text { hosts }\end{array}$} & \multirow{2}{*}{$\begin{array}{l}\text { No. of } \\
\text { ticks }\end{array}$} & \multicolumn{4}{|c|}{ Life stages of ticks } & \multirow{2}{*}{$\begin{array}{l}\text { No. ticks Bbsl-pos./ No. } \\
\text { of ticks tested (\%) }\end{array}$} \\
\hline & & & & $\mathbf{L}$ & $\mathbf{N}$ & $\mathbf{M}$ & $\mathbf{F}$ & \\
\hline I. angustus & $\mathrm{dm}(1)$ & 1 & 1 & 0 & 0 & 0 & 1 & $1 / 1(100)$ \\
\hline I. banksi & bv (8) & 8 & 11 & 0 & 8 & 0 & 3 & $6 / 11(55)$ \\
\hline I. cookei & gh (2), hm (1), mk (1) & 4 & 17 & 0 & 12 & 0 & 5 & $6 / 17(35)$ \\
\hline I. gregsoni & er (2), mk (1) & 3 & 17 & 0 & 14 & 0 & 3 & 4/12 (33) \\
\hline I. muris & ct (2), dm (2), dg (5), mv (2), nss (2), srv (3) & 16 & 16 & 2 & 8 & 0 & 6 & $7 / 16(44)$ \\
\hline I. scapularis & $\operatorname{dg}(9), \mathrm{hm}(3)$ & 12 & 15 & 0 & 0 & 2 & 13 & $5 / 15(33)$ \\
\hline D. albipictus & $\operatorname{dg}(2), \operatorname{ssh}(1)$ & 3 & 5 & 0 & 5 & 0 & 0 & $1 / 4(25)$ \\
\hline H. leporispalustris & $\operatorname{ssh}(5)$ & 5 & 29 & 4 & 21 & 1 & 3 & $9 / 19(47)$ \\
\hline Total & 12 & 52 & 111 & 6 & 68 & 3 & 34 & $39 / 94(41)$ \\
\hline
\end{tabular}

Table 1: Detection of B. burgdorferi s.I. in ixodid ticks collected from mammalian hosts in the vicinity of Kenora, Ontario, 2013-2016. L, larva (e); N, nymph (s); M, male (s); F, female (s); Bbsl, Borrelia burgdorferi s.l.; dm, deer mouse; bv, beaver; gh, groundhog; hm, human; mk, mink; er, ermine; ct, cat; dg, dog; mv, meadow vole; nss, northern short-tailed shrew; srv, southern red-backed vole; ssh, snowshoe hare. 
ethyl alcohol and forwarded to lab B (KLC). These ticks were PCR tested using two sets of primers for the flagellin $\mathrm{B}(\mathrm{flaB})$ gene and one for the 16S-23S rRNA intergenic spacer gene. The flaB PCR assays are species-specific for B. burgdorferi s.l., while the $16 \mathrm{~S}-23 \mathrm{~S}$ spacer PCR is Borrelia genus specific. The $16 \mathrm{~S}-23 \mathrm{~S}$ spacer PCR assay was used to confirm any of the positives obtained using the flaB primers. For ticks collected in the latter stage of the second part of the study, we only used the flaB gene PCRs. The methodology was described earlier in Scott et al. [6]. The negative control consisted of nuclease-free TE buffer. In order to prevent DNA contamination, a positive control was not used. Using the PCR1 and PCR2 primer sets, amplicons (194-bp, base position 313 to 506; 206-bp, base position 532 to 737 ) of the $B$. burgdorferi s.l. flaB gene were obtained from 2 ticks (I. angustus, 14-5A169; I. scapularis, 14-5A207).

In the latter part of the study, ticks were stored in 2 $\mathrm{mL}$ micro tubes containing $94 \%$ ethyl alcohol, and sent directly by courier to lab C (JEF) for testing; the protocols are outlined in Scott and Foley [21].

Because of the special significance of I. gregsoni in the present study, two ticks were kept as voucher specimens rather than being tested for B. burgdorferi s.l. These nymphal ticks (13-5A172, 16-5A96A) have been archived in 95\% ethyl alcohol in the Centre of Biodiversity Genomics (CBG), University of Guelph with accession numbers $\mathrm{BIO}-15-068$ and $\mathrm{BIO}-16-147$, respectively. The DNA extracts are held at $-80^{\circ} \mathrm{C}$ at the same location. DNA extraction, amplification, and sequencing followed the protocol previously described in Scott et al. [22]. The collection data and barcode sequences are stored on the Barcode of Life Datasystems (BOLD; www.boldsystems. org), and can be accessed in the BOLD dataset at: dx.doi. org./10.5883/DS-IGAK. In addition, the sequences have been deposited in GenBank with the accession numbers: KY370928 (for tick 13-5A172N) and KY370927 (for tick 16-5A96A).

The 194-bp nucleotide sequences of the $f l a B$ gene obtained from B. burgdorferi s.l. amplicons were deposited in GenBank with accession numbers: KT827327.1 (from an I. angustus female, 14-5A169) and KT807497.1 (from an I. scapularis female,14-5A207).

\section{Results}

\section{Tick collection}

We obtained 111 ixodid ticks from 52 small-, medium-, and large-sized vertebrate hosts, including humans, representing 12 different mammalian species in the Kenora area (Table 1). They include: cats, Felis catus; dogs, Canis lupus familiaris; deer mice, Peromyscus maniculatus; meadow voles, Microtus pennsylvanicus; northern shorttailed shrew, Blarina brevicauda; and southern redbacked voles, Myodes gapperi. In addition, we collected 20 American dog ticks, Dermacentor variabilis, from mammalian hosts (i.e., dog, deer mice, red fox); however, because this tick species lacks vector competence for $B$. burgdorferi s.l., we did not test any of these specimens.

\section{Spirochete detection}

Lyme disease spirochetes were detected in 8 different species of ticks (Table 1). Overall, 39 (41\%) of 94 ticks tested were positive for B. burgdorferi s.l. When we conducted DNA sequencing with the $f l a B$ gene, we detected B. burgdorferi s.s. in an I. angustus female, 145A169 and likewise, in an I. scapularis female, 14-5A207.

\section{Discussion}

This study reveals that B. burgdorferi s.l. is widely disseminated within an interconnected wildlife ecosystem in the Kenora area. We found 8 different species of ticks in the Kenora area that were positive for B. burgdorferi s.l. These findings show that Lyme disease spirochetes are present in a wide diversity of ticks and mammals throughout this area. Overall, B. burgdorferi s.l.-infected ticks were collected from 12 different mammalian species, including humans.

The Kenora bioregion comprises a diverse and intricately-connected ecosystem that supports numerous ticks, birds, and mammals. This biodiverse system sustains at least 9 tick species. Several small mammals inhabiting the Kenora area are known to be reservoir-competent hosts of B. burgdorferi s.l., namely deer mice [23,24], eastern chipmunk, Tamias striatus [25,26], meadow voles [27], northern short-tailed shrew [4,28], and southern red-backed voles [29]. Although white-tailed deer are not competent reservoirs of $B$. burgdorferi s.l., they support the reproduction of $I$. scapularis ticks [30]. Although whitefooted mice, Peromyscus leucopus, are not indigenous in the Kenora area, these cricetid rodents will retain $B$. burgdorferi s.l. spirochetemias for life [31,32].

In addition to mammals, resident and migratory songbirds disperse bird-feeding ticks in the area, especially during northward spring migration [8-17]. Not only do multiple host species support and maintain Lyme disease vector ticks, Neotropical and southern-temperate songbirds annually transport bird-feeding ticks (i.e., 
Citation: Scott JD, Clark KL, Anderson JF, Foley JE, Young MR, et al. (2017) Lyme Disease Bacterium, Borrelia burgdorferi Sensu Lato, Detected in Multiple Tick Species at Kenora, Ontario, Canada. J Bacteriol Parasitol 8: 304. doi:10.4172/2155-9597.1000304

Ixodes affinis, Ixodes minor) into central Canada during spring migration from as far south as Brazil [10,11,15]. Not only are bird-feeding ticks transported long distances, resident birds disperse Lyme disease vector ticks during the nesting and post-fledgling periods during the summer. Collectively, avian and mammalian hosts are vertebrate cohabitants, and enhance the complex epidemiological cycle of B. burgdorferi s.l. in the Kenora area.

Not only is $I$. scapularis is a competent vector of $B$. burgdorferi s.l. [1,33], I. angustus has vector competency for B. burgdorferi s.l. [34], In addition, Ixodes muris is a competent vector and supports enzootic maintenance of B. burgdorferi s.l. [35]. These particular tick species, plus reservoir hosts, provide multiple opportunities for the interchange of B. burgdorferi s.l. These vector-hostpathogen associations help to maintain and propagate the presence of Lyme disease spirochetes within the environment in the Kenora area.

\section{Ixodes angustus}

A partially engorged $I$. angustus female was collected from a deer mouse near Kenora on 1 August 2014; this is the first report of a B. burgdorferi s.l.-infected I. angustus in Ontario (Figure 1A). Notably, I. angustus is a competent vector of Lyme disease spirochetes [34], and the deer mouse is a reservoir-competent host $[23,24]$. This nidicolous tick species feeds primarily on rodents and shrews, and the male stays in the host nest to mate with females [36].
Zoogeographically, I. angustus has a wide range across the Holarctic Region (including the Temperate Zone of North America) [36,37]. In Canada, Lyme disease spirochetes were initially isolated from I. angustus ticks in British Columbia [38]. In Washington State, Damrow et al. [39] described a human case of Lyme disease with an erythematous lesion, and intimated that the attached I. angustus female was likely the vector of $B$. burgdorferi s.l. There is further evidence to indicate that $I$. angustus acts as a bridge vector of $B$. burgdorferi s.l. to humans [7]. In the present study, DNA sequencing revealed that the Borrelia amplicon from the $I$. angustus female was B. burgdorferi s.s., which is pathogenic to humans and certain domestic animals.

\section{Ixodes banksi}

A partially engorged I. banksi nymph was collected from a beaver, Castor canadensis, on 15 May 2013 at Silver Lake North, Ontario. This constitutes the first report of a $B$. burgdorferi s.l.-infected I. banksi in northwestern Ontario. Previously, a B. burgdorferi s.l.-positive I. banksi was collected at Sault Ste. Marie, Ontario [40]. During 2013, ten I. banksi ticks ( 2 females, 8 nymphs) were collected from 7 beavers north of Kenora, Ontario. With one exception, all beavers were parasitized by at least one B. burgdorferi s.l.infected I. banksi. A partially engorged I. banksi female, 16-5A99, was collected from a beaver on 15 November 2016 at Jim Lake $(50.10 \mathrm{~N}, 94.40 \mathrm{~W})$ near Redditt, Ontario (Figure 1B); this constitutes the northernmost collection of I. banksi in North America.

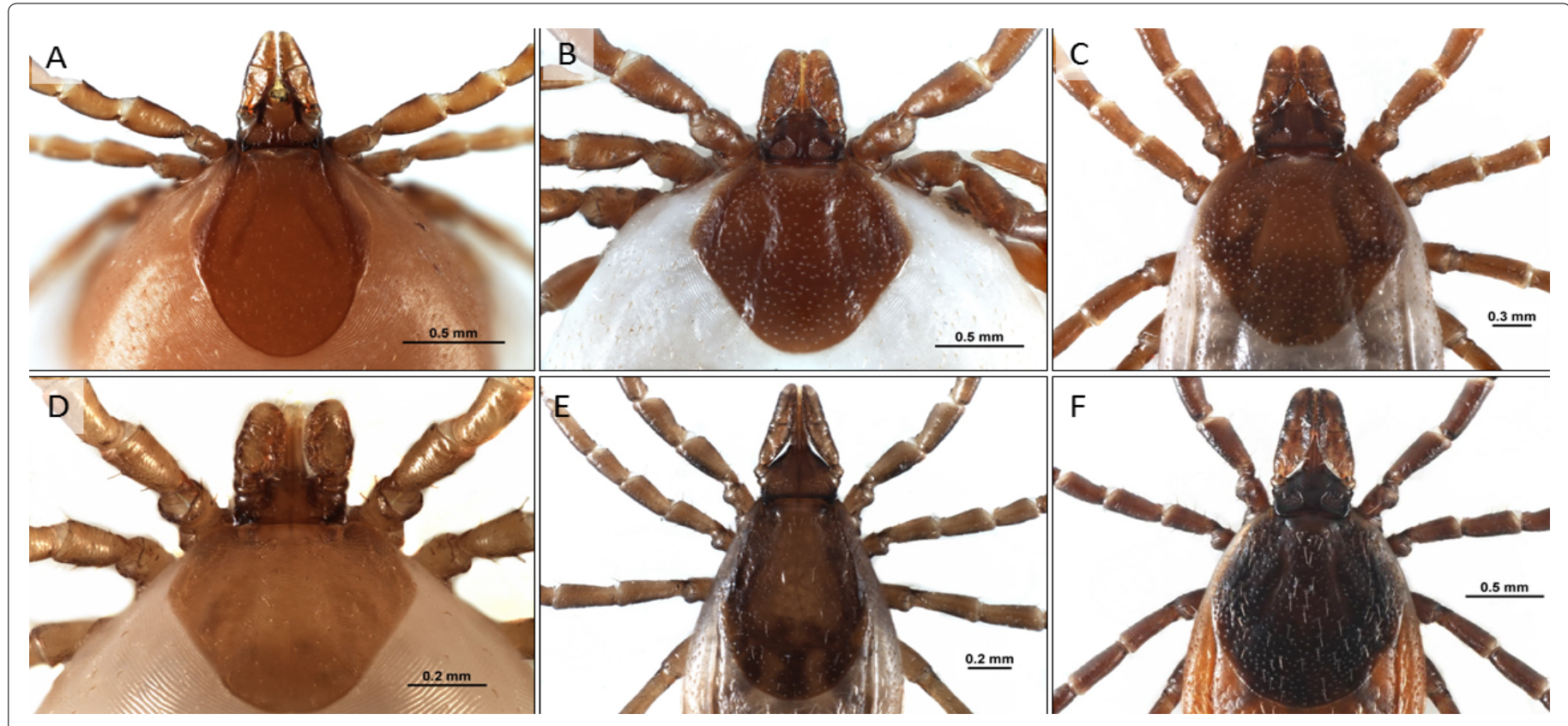

Figure 1: Ixodes species in the Kenora area that were PCR-positive for B. burgdorferi s.l.; capitulum and scutum: A. Ixodes angustus, female; B. Ixodes banksi, female; C. Ixodes cookei, female; D. Ixodes gregsoni, nymph; E. Ixodes muris, female; and F. Ixodes scapularis, female. Photo credits: Elizabeth J. Sears. 
Of note, $I$. banksi is normally found on beavers and muskrats, Ondatra zibethicus, but it has also been recorded to parasitize humans [36]. Based on the nesting habits of beavers and muskrats, I. banksi is likely a nidicolous tick.

\section{Ixodes cookei}

The groundhog tick has a wide host range of terrestrial mammals, and has not been noted as a vector of Lyme disease spirochetes. Barker et al. [41] did not detect $B$. burgdorferi s.l. in any of the host-feeding life stages of I. cookei collected from humans and other animals, and purported that $I$. cookei is a poor vector of Lyme disease spirochetes. On the other hand, Hall et al. [42] reported a woman who had been bitten by an I. cookei nymph in West Virginia, and developed a typical erythema migrans (EM) rash. These latter researchers suggest that $I$. cookei is a vector of Lyme disease spirochetes. In the present study, 3 $(60 \%)$ of 5 I. cookei on two groundhogs were infected with B. burgdorferi s.l. Notably, a human bitten by an I. cookei nymph developed symptoms typical of Lyme disease. In addition, a woman living in southwestern Ontario was bitten by an I. cookei nymph; this tick tested positive for B. burgdorferi s.l., and the woman developed classic symptoms associated with Lyme disease [43]. Our study provides strong circumstantial evidence that $I$. cookei is a vector of B. burgdorferi s.l., and that groundhogs are potential reservoirs of Lyme disease spirochetes.

\section{Ixodes gregsoni}

We provide the first record of Ixodes gregsoni positive for B. burgdorferi s.l. Twelve I. gregsoni ticks (1 female, 11 nymphs; 13-5A172) were collected from an ermine, Mustela erminea, near Kenora on 2 December 2013. Of the 8 nymphs tested, 4 were positive for $B$. burgdorferi s.l. One nymph was deposited in the tick collection of Lance A. Durden with accession number L3659. Likewise, one I. gregsoni nymph was deposited at the Centre for Biodiversity Genomics with accession number BIO-15068; the Process ID is: TJSD015. Currently, this nymph represents the first I. gregsoni specimen with an associated sequence in GenBank. In addition, two I. gregsoni females were collected $45 \mathrm{~km}$ north of Kenora from an ermine on 15 November 2014; both females were negative for $B$. burgdorferi s.l. Previously, Lindquist et al. [44] reported $I$. gregsoni on mustelids as far west as Ignace, Ontario ( $49^{\circ}$ $25^{\prime} \mathrm{N}, 91^{\circ} 41^{\prime} \mathrm{W}$ ).

We collected 3 I. gregsoni nymphs (16-5A96A, B, C) from an American mink, Neovision vison, at Jim Lake, near Redditt, Ontario on 5 November 2016 (Figure 1D). One of these I. gregsoni nymphs was retained for DNA barcoding, and was deposited in the Centre for Biodiversity Genomics; this represents the second sequence record for this tick species. Our collections indicate that the range of I. gregsoni extends westward at least to Kenora and northward to Redditt, which is $200 \mathrm{~km}$ further west than Ignace, Ontario. This recent collection of I. gregsoni at Jim Lake is the northernmost collection of this tick species in North America. Our findings suggest that I. gregsoni ticks may have vector competency for B. burgdorferi s.l.; however, further transmission experiments would be required to determine its vector status.

\section{Ixodes muris}

We collected I. muris from 6 different mammalian host species, namely cats, dogs, deer mice, northern short-tailed shrews, meadow voles, and southern red-backed voles (Table 1). In all, 16 I. muris (6 females, 8 nymphs, 2 larvae) were collected from these mammals, and 7 (44\%) of 16 engorged ticks were positive for B. burgdorferi s.l. (Table 1, Figure 1E). In nature, I. muris has vector competence for $B$. burgdorferi s.l. $[35,45]$ and, consequently, this tick species can acquire spirochetes while feeding on an infected host, pass them transstadially during the moult, and later transmit Lyme disease spirochetes to a susceptible host during engorgement. Ixodes muris sometimes parasitizes cats and dogs, and has also been recorded from humans in New York, Pennsylvania and Rhode Island [46]. Ixodes muris immatures also parasitize rats [36], and all hostfeeding life stages feed on ground-frequenting birds [8$10,12,15,36]$. In essence, I. muris plays a supportive role in the enzootic maintenance of Lyme disease spirochetes in the Kenora area.

\section{Ixodes scapularis}

Blacklegged ticks (Figure 1F) were collected from local dogs and humans with no history of travel. In all, 5 (33\%) of 15 I. scapularis adults were positive for B. burgdorferi s.l. One of the Borrelia amplicons from a B. burgdorferi s.l.infected $I$. scapularis female underwent DNA sequencing, and was characterized as B. burgdorferi s.s., which is pathogenic to humans and certain domestic animals. Historically, Banerjee et al. [4] isolated B. burgdorferi s.l. from an I. scapularis in mainland Ontario; this tick was collected from a dog residing in Kenora, Ontario that had no history of travel. Additionally, a 10-year, tick-host study (1993-2002), which was conducted across Ontario [5], reported B. burgdorferi s.l.-infected blacklegged ticks in the Kenora District. Recently, Scott et al. [6] documented an established population of blacklegged ticks on Corkscrew Island in Lake of the Woods. Notably, this island has an 
infection prevalence of $73 \%$ for B. burgdorferi s.l. in $I$. scapularis adults, the highest known prevalence of Lyme disease spirochetes in Canada. These researchers also found that white-footed mice, which host I. scapularis larvae and nymphs in some parts of North America, do not need to be present to maintain an enzootic cycle of $B$. burgdorferi s.l.

Songbirds (Passeriformes) can transport B. burgdorferi s.l.-infected $I$. scapularis larvae and nymphs to and from this bioregion during bi-directional migration in spring and fall [8-17]. Peak northward songbird migration in Canada occurs during May and early June, which coincides with peak questing periods of I. scapularis nymphs [47]. When southern-temperate and Neotropical songbirds make landfall at migratory stopovers along their flight path, they can be parasitized by I. scapularis immatures, especially nymphs. These bird-feeding ticks subsequently detach, and are released across Canada. As a result, people do not have to visit to another endemic area to contract Lyme disease. In addition, Scott et al. [22] recently discovered that raptors are hosts of I. scapularis ticks.

Biogeographically, I. scapularis is a common vector of Lyme disease spirochetes east of the Rocky Mountains; however, in the Kenora District, other Ixodes species (I. angustus, I. banksi, I. cookei, I. muris) also bite humans. At least 5 species of ticks could transmit B. burgdorferi s.l. to humans in this region. The present study reinforces the fact that $I$. scapularis plays a significant role in the epidemiological transmission cycle of B. burgdorferi s.l. in the Kenora bioregion.

\section{Dermacentor albipictus}

We provide the first record of the winter tick, Dermacentor albipictus, testing positive for B. burgdorferi s.l. On 9 December 2013, three D. albipictus nymphs were collected from a dog in the Kenora, Ontario area with no history of travel. Of particular note, 1 (33\%) of 3 fully engorged nymphs was positive for B. burgdorferi s.l. We did not test the host dog to determine whether it might be infected with B. burgdorferi s.l. Since moose, Alces alces, are common hosts of all 3 host-feeding life stages of $D$. albipictus, it is possible that Lyme disease spirochetes were obtained during a larval bloodmeal from a spirochetemic animal. We are not aware of any previous findings of $D$. albipictus being infected with $B$. burgdorferi s.l.

\section{Haemaphysalis leporispalustris}

Three partially engorged nymphs of the rabbit tick, Haemaphysalis leporispalustris, were collected from a snowshoe hare, Lepus americanus, on 11 October 2013. This lagomorph was located just north of Kenora. Of significance, 2 (67\%) of 3 nymphs were positive for $B$. burgdorferi s.l. This discovery provides the first record of a B. burgdorferi s.l.-positive H. leporispalustris in Ontario. Previously, Banerjee et al. [48] isolated B. burgdorferi s.l. from $H$. leporispalustris collected from a snowshoe hare from Grande Prairie, Alberta; their discovery represents the first isolation of $B$. burgdorferi s.l. from rabbit ticks in Canada. Notably, the first B. burgdorferi s.l.-positive $H$. leporispalustris was collected from a Swainson Thrush, Catharus ustulatus, at Long Point, Ontario [15]. As well, B. burgdorferi s.l. was isolated from H. leporispalustris in Texas [49].

\section{Other Tick Species}

It is noteworthy that Ixodes dentatus larvae and nymphs are transported by migratory songbirds in eastern and central Canada during northward spring migration. Each year, these migrants can drop them in the Kenora bioregion during northward spring migration $[8-10,12,15]$. Moreover, all host-feeding life stages of $I$. dentatus collected from eastern cottontail in New York yielded B. burgdorferi s.l. [50]. This Borrelia was later named B. andersonii [51].

Throughout north-central and northeastern North America, several tick species are sympatric with $I$. scapularis. Likewise, several tick species are cohabitants in the Kenora area, and infest the same hosts. For example, the American dog tick, previously given is prolific in the Kenora area, but this tick species is not a competent vector of B. burgdorferi s.l. However, it is a vector of other tickborne pathogens, namely Francisella tularensis (causative agent of tularemia), Rickettsia rickettsii (agent of Rocky Mountain spotted fever), Ehrlichia chaffeensis (agent of human monocyctic ehlrichiosis), Ehrlichia ewingii (agent of canine granulocytic ehrlichiosis), and some attached females can cause tick paralysis [52].

\section{Neurological manifestations of B. burgdorferi s.s}

We detected B. burgdorferi s.s., which is pathogenic to humans, in ticks collected in theKenora area. This particular B. burgdorferi s.l. genospecies can cause a wide diversity of neurological symptoms, especially in the peripheral nerves and central nervous system. As this spirochetosis advances in the body, the meninges, cranial nerves and peripheral nerve roots may be affected. Neurological Lyme disease includes all forms of encephalitis, encephalomyelitis, meningoencephalitis, and radiculomyelitis [53]. Of note, chronic encephalomyelitis is defined as lasting longer 
than 6 months. Borrelia burgdorferi s.s. infection in the CNS is difficult to recognize because only $14 \%$ of patients recalled a tick bite at the site of an EM rash [54]. Another problem is the variable incidence of the EM rash, which ranges from $27 \%$ to $70 \%$ in Lyme disease studies [55,56]. Patients often see several physicians before the diagnosis is established. Long-lasting and remittent pain may be so intense that patients have significant difficulties with sleep and cannot maintain their jobs. Other complaints include flu-like symptoms with myalgia; arthralgia without joint swelling; profound fatigue and general malaise; weight loss; nausea and vomiting; transient weakness; and prickly sensations in extremities $[57,58]$.

Not only are motor and sensory systems affected by neurological Lyme disease, balance is often altered. Ataxia of legs and gait occur in up to $60 \%$ of patients with CNS involvement [59]. Like other encephalitic diseases, chronic CNS Lyme disease often presents with neuropsychiatric symptoms. Concentration problems, fatigue, and depression may precede the onset of dementialike symptoms [60]. Symptoms of dementia include cognitive impairment, memory loss, disorientation and, also psychiatric disorders [56]. In one patient who was suffering from a mild organic brain disorder, Alzheimer's disease was diagnosed before the patient died [61]. At autopsy, B. burgdorferi s.l. was detected in and cultured from the brain tissue. Other researchers have cultured and detected B. burgdorferi s.l. in the brains of psychiatric and Alzheimer's disease patients at autopsy [62-67]. Persistence of $B$. burgdorferi s.l. is clearly documented in Lyme disease patients [68-70].

Brain magnetic resonance imaging often shows hyperintense white matter lesions in patients with advanced neurological Lyme disease [53]. These lesions may mimic demyelination that occur in multiple sclerosis [58]. Neurological Lyme disease can be fatal in neonates and infants [71,72]. A newborn whose mother had suffered from Lyme disease during early pregnancy died 23 hours after birth, and B. burgdorferi s.l. was demonstrated in the brain and liver by silver staining and immunochemistry [73]. In addition, Lyme disease is sometimes fatal in children and adults [74,75]. In late stage neurological Lyme disease, patients may become bedridden and confined to a wheelchair. This multisystem disease can also lead to optic nerve damage and cause blindness [69], and leave patients compromised and sometimes unable to pursue education or occupation.

\section{Conclusions}

Our findings disclose that B. burgdorferi s.l. is widely disseminated in 8 species of ticks inhabiting the environment encompassing Kenora, Ontario. When humans contract Lyme disease, they can experience multiple clinical manifestations, including significant neurological involvement. Ultimately, B. burgdorferi s.s.infected ticks have an interconnecting link with humans and companion animals in the Kenora area. Transmission experiments need to be completed to determine if some of these ticks, such as I. gregsoni, are competent vectors of B. burgdorferi s.l. Notably, humans and companion animals engaging in outdoor activities are vulnerable to contracting Lyme disease and associated tick-borne diseases. The medical practitioners must be aware that Lyme disease vector ticks pose a public health risk in the Kenora area.

\section{Acknowledgments}

We thank wildlife biologists, veterinarians, fur harvesters, field co-operators and the public for collecting ticks. We are grateful to Elizabeth E. Alves, Angela Bransfield, and Kenny Lou for technical assistance. We are indebted to Elizabeth J. Sears for taking photographs of ticks and fulfilling computer graphics. Funding for this study was supported in part by Lyme Ontario.

\section{References}

1. Burgdorfer W, Barbour AG, Hayes SF, Benach JL, Grunwaldt E, et al. (1982) Lyme disease - a tick-borne spirochetosis? Science 216: 1317-1319.

2. Anderson JF, Magnarelli LA (1984) Avian and mammalian hosts for spirochete-infected ticks and insects in a Lyme disease focus in Connecticut. Yale J Biol Med 57: 627-641.

3. Nicholson WL, Sonenshine DE, Lane RS, Uilenberg G (2009) Ticks (Ixodoidea). In: Mullen GR, Durden LA (eds). Medical and Veterinary Entomology, 2nd edn. Elsevier, Inc, Amsterdam, The Netherlands. pp: 493-542.

4. Banerjee SN, Christensen CI, Scott JD (1995) Isolation of Borrelia burgdorferi on mainland Ontario. Can Commun Dis Rep 21: 85-86.

5. Morshed MG, Scott JD, Fernando K, Geddes G, McNabb A, et al. (2006) Distribution and characterization of Borrelia burgdorferi isolates from Ixodes scapularis and presence in mammalian hosts in Ontario, Canada. J Med Entomol 43: 762-773.

6. Scott JD, Foley JE, Clark KL, Anderson JF, Durden LA, 
et al. (2016) Established population of blacklegged ticks with high infection prevalence for the Lyme disease bacterium, Borrelia burgdorferi sensu lato, on Corkscrew Island, Kenora District, Ontario. Int J Med Sci 13: 881891.

7. Eisen L, Lane RS (2002) Vectors of Borrelia burgdorferi sensu lato. In: Gray J, Kahl O, Lane RS, Stanek G (eds). Lyme borreliosis: biology, epidemiology and control. CABI Publishing, New York. pp: 91-115.

8. Scott JD, Fernando K, Banerjee SN, Durden LA, Byrne SK, et al. (2001) Birds disperse ixodid (Acari: Ixodidae) and Borrelia burgdorferi-infected ticks in Canada. J Med Entomol 38: 493-500.

9. Scott JD, Lee MK, Fernando K, Durden LA, Jorgensen DR, et al. (2010) Detection of Lyme disease spirochete, Borrelia burgdorferi sensu lato, including three novel genotypes in ticks (Acari: Ixodidae) collected from songbirds (Passeriformes) across Canada. J Vect Ecol 35: 124-139.

10. Scott JD, Anderson JF, Durden LA (2012) Widespread dispersal of Borrelia burgdorferi-infected ticks collected from songbirds across Canada. J Parasitol 98: 49-59.

11. Scott JD, Clark KL, Foley JE, Durden LA, Manord JM, et al. (2016) First record of Ixodes affinis tick (Acari: Ixodidae) infected with Borrelia burgdorferi sensu lato collected from a migratory songbird in Canada. J Bacteriol Parasitol 7: 3.

12. Morshed MG, Scott JD, Fernando K, Beati L, Mazerolle DF, et al. (2005) Migratory songbirds disperse ticks across Canada, and first isolation of Lyme disease spirochete, Borrelia burgdorferi, from the avian tick, Ixodes auritulus. J Parasitol 91: 780-790.

13. Odgen NH, Lindsay LR, Hanincová K, Barker IK, Bigras-Poulin M, et al. (2008) Role of migratory birds in introduction and range expansion of Ixodes scapularis ticks and of Borrelia burgdorferi and Anaplasma phagocytophilum in Canada. Appl Environ Microbiol 74: 1780-1790.

14. Scott JD, Durden LA (2009) First isolation of Lyme disease spirochete, Borrelia burgdorferi, from ticks collected from songbirds in Ontario, Canada. North Am Bird Band 34: 97-101.

15. Scott JD, Durden LA (2015) Songbird-transported tick Ixodes minor (Ixodida: Ixodidae) discovered in Canada. Can Entomol 147: 46-50.

16. Scott JD, Durden LA (2015) New records of the Lyme disease bacterium in ticks collected from songbirds in central and eastern Canada. Int J Acarol 41: 241-249.

17. Scott JD (2015) Birds widely disperse pathogen-infected ticks. In: Mahala G, (ed). Seabirds and Songbirds: Habitat Preferences, Conservation and Migratory Behaviour. Nova Science Publishers, Inc, New York. pp: 1-22.

18. Persing DH, Telford SR III, Spielman A, Barthold SW (1990) Detection of Borrelia burgdorferi infection in Ixodes dammini ticks with the polymerase chain reaction. J Clin Microbiol 28: 566-572.

19. Persing DH, Telford SR, Rys PN, Dodge DE, White TJ, et al. (1990) Detection of Borrelia burgdorferi DNA in museum specimens of Ixodes dammini ticks. Science 249: 1420-1423.

20. Scott JD, Anderson JF, Durden LA (2013) First detection of Lyme disease spirochete Borrelia burgdorferi in ticks collected from a raptor in Canada. J Vet Sci Med Diagn 2: 4 .

21. Scott JD, Foley JE (2016) Detection of Borrelia americana in the avian coastal tick, Ixodes auritulus (Acari: Ixodidae), collected from a bird captured in Canada. Open J An Sci 6: 207-216.

22. Scott JD, Foley JE, Young MR, Durden LA (2017) First report of a blacklegged tick, Ixodes scapularis Say (Acari: Ixodidae), parasitizing a raptor in Canada. Syst Appl Acarol 22: 208-216.

23. Loken KI, Wu CC, Johnson RC, Bey RF (1985) Isolation of the Lyme disease spirochete from mammals in Minnesota. Proc Soc Exp Biol Med 179: 300-302.

24. Peavey CA, Lane RS (1995) Transmission of Borrelia burgdorferi by Ixodes pacificus nymphs and reservoir competence of deer mice (Peromyscus maniculatus) infected by tick-bite. J Parasitol 81: 175-178.

25. Anderson JF, Magnarelli LA, Burgdorfer W, Barbour AG (1983) Spirochetes in Ixodes dammini and mammals from Connecticut. Am J Trop Med Hyg 32: 818-824.

26. McLean RG, Ubico SR, Cooksey LM (1993) Experimental infection of the eastern chipmunk (Tamias striatus) with the Lyme disease spirochete (Borrelia burgdorferi). J Wildl Dis 29: 527-532.

27. Markowski D, Ginsberg HS, Hyland KE, Hu R (1998) Reservoir competence of the meadow vole (Rodentia: Cricetidae) for the Lyme disease spirochete Borrelia burgdorferi. J Med Entomol 35: 804-808.

28. Telford SR 3rd, Mather TN, Adler GH, Spielman A 
(1990) Short-tailed shrews as reservoirs of the agents of Lyme disease and human babesiosis. J Parasitol 76: 681683.

29. Stone BL, Russart MM, Gaultney RA, Flodon AM, Vaughan JA, et al. (2015) The western progression of Lyme disease: infectious and nonclonal Borrelia burgdorferi sensu lato populations in Grand Forks County, North Dakota. Appl Environ Microbiol 81: 4858.

30. Telford SR 3rd, Mather TN, Moore SI, Wilson ML, Spielman A (1988) Incompetence of deer as reservoirs of the Lyme disease spirochete. Am J Trop Med Hyg 39: 105-109.

31. Donahue JG, Piesman J, Spielman A (1987) Reservoir competence of white-footed mice for Lyme disease spirochetes. Am J Trop Med Hyg 36: 92-96.

32.Schwan TG, Karstens RH, Schrumpf ME, Simpson WJ (1991) Changes in antigenic reactivity of Borrelia burgdorferi, the Lyme disease spirochete, during persistent infection in mice. Can J Microbiol 37: 450454.

33. Sanders FH Jr, Oliver JH Jr (1995) Evaluation of Ixodes scapularis, Amblyomma americanum and Dermacentor variabilis (Acari: Ixodidae) from Georgia as vectors of a Florida strain of the Lyme disease spirochete, Borrelia burgdorferi. J Med Entomol 32: 402-406.

34. Peavey CA, Lane RS, Damrow T (2000) Vector competence of Ixodes angustus (Acari: Ixodidae) for Borrelia burgdorferi sensu stricto. Exper Appl Acarol 24: 77-84.

35. Dolan MC, Lacombe EH, Piesman J (2000) Vector competence of Ixodes muris (Acari: Ixodidae) for Borrelia burgdorferi. J Med Entomol 37: 766-768.

36. Durden LA, Keirans JE (1996) Nymphs of the genus Ixodes (Acari: Ixodidae) of the United States: taxonomy, identification key, distribution, hosts, and medical/ veterinary importance. Monographs, Thomas Say Publications in Entomology. Entomological Society of America, Lanham, Maryland, USA.

37. Robbins RG, Keirans JE (1992) Systematics and ecology of the subgenus Ixodiopsis (Acari: Ixodidae: Ixodes). Monographs, Thomas Say Publications in Entomology, Vol. XIV. Entomological Society of America, Lanham, Maryland, USA.

38. Banerjee SN, Banerjee $M$, Smith JA Fernando K (1994) Lyme disease in British Columbia-an update. Proceedings of the VII Annual Lyme Disease Foundation International Scientific Conference, Stamford, Connecticut.

39. Damrow T, Freedman H, Lane RS, Preston KL (1989) Is Ixodes (Ixodiopsis) angustus a vector of Lyme disease in Washington State? West J Med 150: 580-582.

40. Banerjee S, Banerjee M, Scott J, Lankester M, Kubinec J (1996) Isolation of Borrelia burgdorferi — Thunder Bay District, Ontario. Can Commun Dis Rep 22: 138-140.

41. Barker IK, Lindsay LR, Campbell GD, Surgeoner GA, McEwen SA (1993) The groundhog tick Ixodes cookei (Acari: Ixodidae): a poor potential vector of Lyme borreliosis. J Wildl Dis 29: 416-422.

42. Hall JE, Amrine JW Jr, Gais RD, Kolanko VP, Hagenbuch BE, et al. (1991) Parasitization of humans in West Virginia by Ixodes cookei (Acari: Ixodidae), a potential vector of Lyme borreliosis. J Med Entomol 28: 186-189.

43. Scott JD, Foley JE, Anderson JF, Clark KL, Durden LA (2017) Detection of Lyme disease bacterium, Borrelia burgdorferi sensu lato, in blacklegged ticks collected in the Grand River valley, Ontario, Canada. Int J Med Sci 14: 150-158.

44. Lindquist EE, Wan Wu K, Redner JH (1999) A new species of the tick genus Ixodes (Acari: Ixodidae) parasitic on mustelids (Mammalia: Carnivora) in Canada. Can Entomol 131: 151-170.

45. Oliver JH Jr (1996) Lyme borreliosis in the southern United States: a review. J Parasitol 82: 926-935.

46. Merten HA, Durden LA (2000) A state-by-state survey of ticks recorded from humans in the United States. J Vector Ecol 25: 102-113.

47. Mannelli A, Kitron U, Jones CJ, Slajchert TL (1994) Influence of season and habitat on Ixodes scapularis infestation on white-footed mice in northwestern Illinois. J Parasitol 80: 1038-1042.

48. Banerjee SN, Banerjee M, Fernando K, Dong MY, Smith JA, et al. (1995) Isolation of Borrelia burgdorferi, the Lyme disease spirochete from rabbit ticks, Haemaphysalis leporispalustris from Alberta. Can Commun Dis Rep 21: 86-88.

49. Rawlings J, Tetlow G (1990) Update: Lyme borreliosis in Texas. Proceedings of the 45th Annual Meeting, INCDNCM, Hamilton, MO.

50. Anderson JF, Magnarelli LA, LeFebvre RB, Andreadis TG, McAninch JB, et al. (1989) Antigenically variable 
Borrelia burgdorferi isolated from cottontail rabbits and Ixodes dentatus in rural and urban areas. J Clin Microbiol 27: 13-20.

51. Marconi RT, Liveris D, Schwartz I (1995) Identification of novel insertion elements, restriction fragment length polymorphism patterns, and discontinuous $23 \mathrm{~S}$ rRNA in Lyme disease spirochetes: phylogenetic analyses of rRNA genes and their intergenic spacers in Borrelia japonica sp. nov. and genomic group 21038 (Borrelia andersonii sp. nov.) isolates. J Clin Microbiol 33: 2427-2434.

52. Ladislav S, Sonenshine DE, Park Y, Žitnan D (2014) Nervous and sensory systems: structure, function, genomics, and proteomics. In: Sonenshine DE, Roe RM, (ed). Biology of Ticks, 2nd edn, Vol 1. Oxford University Press, Oxford, England, New York, USA. pp: 309-367.

53. Martin R, Kohlhepp W, Mertens HG (1993) Chronic central nervous system involvement. In: Burgdorfer W, Weber K (eds). Aspects of Lyme borreliosis. SpringerVerlag, Berlin: 205-218.

54. Berger BW (1989) Dermatologic manifestations of Lyme disease. Rev Infect Dis 11 Suppl 6: S1475-1481.

55. Bingham PM, Galetta SL, Athreya B, Sladky J (1995) Neurologic manifestations in children with Lyme disease. Pediatrics 96: 1053-1056.

56. Stricker RB, Phillips SE (2003) Lyme disease without erythema migrans: cause for concern? Am J Med 115: 73-74.

57. Pachner AR, Duray P, Steere AC (1989) Central nervous system manifestations of Lyme disease. Arch Neurol 46: 790-795.

58. Kohler J, Kern U, Kasper J, Rhese-Küpper B, Thoden U (1988) Chronic central nervous system in Lyme borreliosis. Neurology 38: 863-867.

59. Weder B, Wiedersheim P, Matter L, Steck A, Otto F (1987) Chronic progressive neurological involvement in Borrelia burgdorferi infection. J Neurol 234: 40-43.

60. Bensch J, Olcen P, Hagberg L (1987) Destructive chronic Borrelia meningoencephalitis in a child untreated for 15 years. Scand J Infect Dis 19: 697-700.

61. MacDonald AB, Miranda JM (1987) Concurrent neocortical borreliosis and Alzheimer's disease. Hum Pathol 18: 759-761.

62. MacDonald AB (1986) Borrelia in the brains of patients dying with dementia. JAMA 256: 2195-2196.

63. MacDonald AB (2006) Plaques of Alzheimer's disease originate from cysts of Borrelia burgdorferi, the Lyme disease spirochete. Med Hypotheses 67: 592-600.

64. MacDonald AB (2007) Alzheimer's neuroborreliosis with trans-synaptic spread of infection and neurofibrillary tangles derived from intraneuronal spirochetes. Med Hypotheses 68: 822-825.

65. Miklossy J (1993) Alzheimer’s disease —a spirochetosis? Neuroreport 4: 841-848.

66. Miklossy J, Kis A, Radenovic A, Miller L, Forro L, et al. (2006) Beta-amyloid deposition and Alzheimer's type changes induced by Borrelia spirochetes. Neurobiol Aging 27: 228-236.

67. Miklossy J (2011) Alzheimer's disease - a neurospirochetosis. Analysis of the evidence following Koch's and Hill's criteria. J Neuroinflammation 8: 90.

68. Sapi E, Bastian SL, Mpoy CM, Scott S, Rattelle A, et al. (2012) Characterization of biofilm formation by Borrelia burgdorferi in vitro. PLoS One 7: e48277.

69. Preac-Mursic V, Pfister HW, Spiegel H, Burk R, Wilske B, et al. (1993) First isolation of Borrelia burgdorferi from an iris biopsy. J Clin Neuroophthalmol 13: 155-161.

70. Häupl T, Hahn G, Rittig M, Krause A, Schoerner C, et al. (1993) Persistence of Borrelia burgdorferi in ligamentous tissue from a patient with chronic Lyme borreliosis. Arthritis Rheum 36: 1621-1626.

71. MacDonald AB (1989) Gestational Lyme borreliosis implication for the fetus. In: Johnson RC (ed). Rheumatic disease clinics of North America. Vol 15. WB. Saunders Company, Philadelphia. pp: 657-677.

72. Gardner T (2001) Lyme disease. In: Remington JS, Klein JO (eds). Infectious diseases of the fetus and newborn infant. WB. Saunders Company, Philadelphia. pp: 519641.

73. Weber K, Bratzke HJ, Neubert U, Wilske B, Duray PH (1988) Borrelia burgdorferi in a newborn despite oral penicillin for Lyme borreliosis during pregnancy. Pediatr Infect Dis J 7: 286-289.

74. Oksi J, Kalimo H, Marttila RJ, Marjamäki M, Sonninen P, et al. (1996) Inflammatory brain changes in Lyme borreliosis. A report on three patients and review of literature. Brain 119: 2143-2154.

75. Liegner KB, Duray P, Agricola M (1997) Lyme disease and the clinical spectrum of antibiotic responsive chronic meningoencephalomyelitides. J Spir Tick-borne Dis 4: 61-73. 